\title{
Collapse of Big Banks in Ghana:Lessons on Its Corporate Governance
}

\author{
Agyemang Andrew Osei ${ }^{1 *} \quad$ Kong Yusheng ${ }^{1} \quad$ Ayamba Emmanuel Caesar ${ }^{1}$ \\ Vincent Konadu Tawiah ${ }^{2}$ Twum Kissiwaa Angelina ${ }^{1}$ \\ 1.School of Finance \& Economics, Jiangsu University, 212013 Xuefu Road, Zhenjiang City, China \\ 2.Department of Accounting, Griffith University, Brisbane City, Australia
}

\begin{abstract}
Funding: National Natural Science Foundation of China (No. 71371087)
Abstract

The news that two indigenous banks, UT and Capital Bank have been taken over by GCB Bank has come as a shock to many Ghanaians, as just a year ago, Capital Bank was adjudged the Best Growing Bank, and Best Bank in Deposits \& Savings at the15th Edition of Ghana Banking Awards while UT Bank was adjudged best bank in 2011 by the same institution. UT bank is one of Ghana's most celebrated brands, after it evolved from a microfinance company into a successful bank. The study reveals the weak compliance to common Corporate Governance practices within the two banks. Specifically, the two banks had small board size as compared to the standard size of the banking industry. Also, the boards did not have enough committees to discharge its operation. The independence of the boards was also impaired as in most of the directors are executives and the non-executive directors have a close relationship with the promoters and executives.
\end{abstract}

Keywords: Corporate Governance, Collapse, Commercial Banks, Board of Directors

DOI: $10.7176 /$ RJFA/10-10-04

Publication date:May $31^{\text {st }} 2019$

\section{Introduction}

Major corporate failures worldwide have dented investor confidence as well as raised several questions on the effectiveness of a firm's internal control system and governance structures Clarke (2007). Indeed, the theme making the headlines for the past years is Corporate Governance (CG). Broadly speaking, CG is all about making sure that decisions are made effectively. This impetus towards corporate governance has been due to many factors. For instance, it protect shareholders from excessive abuse of directors while improving access to capital for the company itself and instilling financial stability in the market Clarke (2004).

Corporate governance is sometimes viewed as a business culture fostering economic growth by building up confidence of investors Commission (2003). Nerantzidis et al. (2012) adopted a more concise definition relating to a company: "corporate governance is the totality of the institutional and organizational mechanisms, and the corresponding decision-making, intervention and control rights, which serve to resolve conflicts of interest between the various groups which have a stake in a firm and either in isolation or in their interaction, determine how important decisions are taken in a firm, and ultimately also determine which decisions are taken". It is to be noted that notwithstanding the numerous theories that have been used as an approach to CG, there are two main principles that prevail and are continuously been applied. These are conformance issues (relating to directors' obligations) and performance issues. The conformance dimension concentrate on an implementation of a regulatory model of operation for directors and concerns issues like board structures and their roles for instance. Both needs to be balanced to maximize the chance of business success. Conversely, the performance issues encourage strategic value and promote the key drivers of performance. In the early 2000s, there was evidence that CG was being induced fundamentally by conformance issues as Board of Directors (Bodtker and Katz Jameson) seeks to uphold their mechanisms as propounded by Roberts et al. (2005). However, Nicholson and Kiel (2004), (Grais and Pellegrini, 2006)argued that too much focus was put on conformance issues to the detriment of performance dimensions and noticed the failure of CG processes to act as a catalyst for performance.

The literature carries mixed results concerning the association between corporate governance and financial performance. Klapper and Love (2004) found a high positive association between better governance and operating performance using firm-level data of 14 emerging stock markets with return on assets as a proxy for operating performance, although affirming that this may vary among countries. Likewise, some other researchers (Gompers et al., 2003, Brown and Caylor, 2004) reported a positive relationship between the quality of CG and their measures of profitability. Also, there is international evidence suggesting this positive link on certain developed markets. For instance, (Selvaggi and Upton, 2008) claimed that good CG enhances firm's performance for the United Kingdom and found the presence of a strong causality between the two variables. Similarly, (Bhagat and Black, 2001) reported the same conclusions in the case of Russian firms. In contrast, other studies reported no significant positive relationship between operating performance and CG. A similar outcome was also observed by (Beiner et al., 2004) using listed Swiss companies.

The motivation of this research is to investigate the sudden collapse of these celebrated banks. These banks 
had in previous years received several awards for their performance. Hence, the collapse of these banks was least expected. Also, the study seeks to investigate corporate governance practices in an emerging economy on domestic financial institutions. Most research on CG practices normally focuses on firms other than banking or financial institutions. This study therefore tries to close the gap by investigating domestic financial institutions.

The broad aim of the study is to tap the actual compliance with the CG provisions by the two collapsed Ghanaian banks, and more importantly to probe into the relationship between CG practice and its effect on performance

Our study reveals the weak compliance to common CG practices within the two banks. Specifically, the two banks had small board size as compared to the standard size of the banking industry. Also, the boards did not have enough committees to discharge its operation. The independence of the boards was also impaired as in most of the directors are executives and the non-executive directors have a close relationship with the promoters and executives.

The contributions of this study are: it highlights the connection between compliance and failures of corporate governance principles in financial institutions. It also brings to light some of the difficulties domestic financial institutions are likely to face if they fail to adhere to good corporate governance principles. Lastly, the study identifies the effects of bringing cronies into businesses.

The rest of this paper is organised as follows: section 2 looks at Literature Review (Banking in Ghana, profile of UT and Capital Bank and also the revoke of banking license), section 3 discusses board effectiveness principles of good corporate governance and relates to the practices of the two banks. Section 4 discusses the implications and lessons learnt and section 5concludes the paper.

\section{Literature Review}

\subsection{Banking in Ghana}

In 1891 George Neville, a representative of Elder Dempster \& Co in Lagos, Nigeria, recognised that banking facilities were urgently required in West Africa, especially in Lagos (IJIMDIYA, 2016). Neville approached the African Banking Corporation, established in South Africa in 1891. Its board of directors in London agreed to extend their business operations to Lagos. The Bank of British West Africa (BBWA) was registered as a limited liability company by the directors of Elder Dempster and began trading on March 31 1894, initially in England and in Lagos. In 1896, a new branch of the Bank was opened in Accra and in the Gold Coast now known as Ghana (MacDonald, 1998). Shortly after the Bank was established in Accra it was able to acquire the business of maintaining the Government accounts. In addition, it was able to introduce the use of cheques in settlement of Government accounts which helped to advertise the usefulness of the Bank to the public. By 1918, the operations of BBWA in the Gold Coast had been so successful that another expatriate bank, the Colonial Bank decided to commence banking there. In 1925 the Colonial Bank merged with the Anglo-Egyptian Bank, the National Bank of South Africa and Barclays Bank. Barclays soon developed into a strong competitor of BBWA (Woldie et al., 2008).

From the late 1920s until the early 1950s, banking services in the Gold Coast continued to be exclusively provided by these two expatriate banks. They functioned largely as commercial banks, facilitating the trading of commercial firms and assisting in revenue collection and the payment of salaries by the Colonial Government (MacDonald, 1998). Branches were opened in many of the provincial capital towns and in the main trading centres in the Gold Coast Colony, and, subsequently, in Ashanti and the Northern Territories of the Gold Coast. In 1953 the Bank of the Gold Coast was set up by the Government and Alfred Engleston, formerly of the Bank of England. Eventually the Bank was split into two: the Bank of Ghana, operating as a bank of issue, to be developed into a complete central bank; and the Ghana Commercial Bank, to be developed into the largest commercial bank with a monopoly on the accounts of public corporations (Stiglitz and Uy, 1996).

The advent of the new Government, elected by popular vote in 1957, brought the establishment of more banks. Banks incorporated by legislation between the period 1957 to 1965 include: the Ghana Investment Bank as an Investment Banking Institution; the Agricultural Development Bank for the development of Agriculture; the Merchant Bank for merchant banking; and the Social Security Bank to encourage savings (Gatsi and Akoto, 2010). In conformity with the economic policy of the time all these institutions were incorporated as state-owned banks.

The Banking Law was enacted in 1989, enabling suitable locally incorporated bodies to file applications for licences to operate as banking institutions (MacCarthy and Dery, 2016). Subsequently, a number of corporate entities were licensed to operate as banks, including Meridien (BIAO) Trust Bank, CAL Merchant Bank, Allied and Metropolitan and ECOBANK. Provision is made for the licensing of non-banking financial institutions under the Financial Institutions (Non-Banking) Law 1993 (P.N.D.C.L. 328). This legislation makes provision for the licensing of non-banking financial institutions seeking to operate as, inter alia, discount companies, finance houses, building societies, or leasing and hire-purchase companies. Such institutions now include the Home Finance Corporation which provides finance for the acquisition of houses and the City Savings and Loans Limited which grants various forms of financial assistance and accommodation to small scale business enterprises. 
As at December $31^{\text {st }}, 2016$, there were 37 registered and licensed commercial banks in Ghana (Owusu et al., 2016). For almost a year now, the industry has been buzzing with news of an imminent adoption of risk-based capital requirement. What this means is that the capital of each bank will be directly linked to the amount of risk inherent in the bank's portfolio. To optimise capital requirement therefore, banks will have to be selective in the type of businesses and individuals to do business with. Given that Ghana's economy has a significant presence of micro and small scale private sector players, whose structures and operations are, predominantly, informal (Gerxhani, 2004).

\subsection{Profile of Collapsed Banks UT Bank}

Joseph Nsonamoa Prince Kofi Amoabeng in 1997 co-founded a Financial services and then named it as Unique Trust (UT) Financial Services. UT Financial Services was a non-bank financial services provider (NBFI) in Ghana, which was incorporated in 1997.Over time, the NBFI acquired subsidiaries and was listed on the Ghana Stock Exchange, under its holding company, UT Holdings Limited. In 2008, UT Holdings Limited acquired majority shareholding in a Ghanaian commercial bank called BPI Bank. The bank was re-branded as UT Bank Ghana Limited and opened for business in May 2009. In June 2010, UT Bank and UT Financial Services Merged into one new company called UT Bank Ghana Limited. Through a reverse listing on the GSE, the new bank's shares became listed and those of UT Holdings were de-listed. Its shares trade under the symbol: UT Bank. As of January 2014, UT Bank maintained a network of Thirty (30) interlinked branches across all regions of Ghana.

UT Bank Limited is a Ghana-based bank that provides a range of value-added products. The Bank's products include Personal Banking, Electronic Banking, Business Banking and Treasury Services. Its Personal Banking product caters for accounts designed for the individual costumer. Its accounts under personal banking include current account, unique account and foreign currency account. Its Electronic Banking products include fonBank, iBank, Tranz-alert and Visa Card. Its Business Banking caters for the needs of small and medium-sized enterprises (SME) market with various financial solutions. The Bank helps its clients trade across borders, and ensures delivery and collection of payments. Its Treasury Services is designed to help its clients with products and solutions for receiving/collecting money for business service.

Capital Bank

Capital Bank (previously First Capital Plus Bank) was an indigenous and commercial Ghanaian bank. It was one of the private national development and commercial banks licensed by Bank of Ghana, the national banking regulator. Capital Bank was founded by William Ato Essien on 29 October 2009 as a microfinance company. As the assets of the company grew, it became a Savings and Loans Company known as First Capital Plus Saving and Loans Company. In 2010 the microfinance grew its deposit base to 36.06 million cedis and total asset size of 47.18 million cedis. In 2013 First Capital Plus Bank (FCP) had deposit base of 211.11 million cedis and total assets of 286.80 million cedis. The Bank of Ghana states that FCP has a market share of $16 \%$ of the advances of savings and loans companies and $19 \%$ of the sector total assets. Before the closure of the bank, it employed 355 and personnel and had 15 branches covering five regions. The Bank grew its base deposit and assets from its inception till 2013 when it applied and was awarded a provisional universal banking license in July, 2012. After the six-month provisional period, the bank was given a full license on 4 December 2013 and became officially known as First Capital Plus Bank. The firm later re-branded to Capital Bank in 2015.

The bank offered mainstream banking services which include cash deposits and withdrawals, savings and loans and financial advice consultation. In 2011 it introduced a cash deposit service known as Speed Banking. The service allows bank customers to deposit cash into their bank accounts at their convenience through their mobile phones without physically being present in any bank branch. The bank as at December 2015 has eighteen operational branches in regions across Ghana.

\subsection{Revoke of Banking License}

On August 14th 2017, the Central Bank of Ghana made a press release indicating that the license of UT Bank had been revoked along with another Ghanaian owned bank (Capital Bank). In the same statement, the Central Bank also approved the take-over of UT Bank and Capital Bank by The Ghana Commercial Bank. The first paragraph of the statement read "The Bank of Ghana has approved a Purchase and Assumption transaction with GCB Bank Ltd that transfers all deposits and selected assets of UT Bank Ltd and Capital Bank Ltd to GCB Bank Ltd. The Bank of Ghana has revoked the License of UT Bank Ltd and Capital Bank Ltd. This action has become necessary due to severe impairment of their capital. The remaining assets and liabilities will be realized and settled respectively through a receivership process to be undertaken by Messers Vish Ashiagbor and Eric Nana Nipah of PricewaterhouseCoopers (PwC)". On the same day the Ghana Stock Exchange announced that it had suspended the listing of UT Bank indefinitely. (www.bog.com) 


\section{Board Effectiveness Principles of Corporate Governance}

Boards of banking entities are quite different from boards of non-financial firms. In particular, boards in the banking sector tend to be bigger and more independent than those in the non-financial sector (Meyer et al., 2012). These directors are subject to mores scrutiny than directors of publicly traded non-bank corporations. In addition to being accountable to shareholders and the securities and exchange regulators, they are accountable to banking regulators. Unlike other directors, bank directors are also accountable to other stake holders including depositors. This is because, individual bank failures can have spillover effects on other banks. They may also face greater liability risk than directors of non-bank entities (Adams, 2012)and play a key advisory role to managers regarding strategy identification and implementation(Meyer et al., 2012).

For this study, we will emphasize Board Effectiveness principle of good Corporate Governance. Under the umbrella of board effectiveness, is composite of other factors. However, board composition, size, independence, gender diversity, CEO / Chairman duality, committees of board and performance as the key parameters. The study will analyse the annual report of UT Bank and Capital Bank from the period of its inception till December, 2016 to determine board effectiveness principle of good corporate governance. A descriptive analysis will be employed to explain the results.

\subsection{Board Size}

A board of limited size is expected to be more performing than bigger ones due to better communication and decision making thus improving performance (Meyer et al., 2012). Board of directors are one of the most important elements of corporate governance mechanism in overseeing the conduct of a company's business and ensures that it was properly managed by their agents. Donnelly and Mulcahy (2008) argued that a company reduced information asymmetry between its managers and other stakeholders by having a large board size. Ahn et al. (2010) suggests that individuals with multiple directorships have limited capacity and time to monitor managers' actions. More importantly, they become too busy to provide useful advice on critical strategic decisions, leaving managers to pursue their own private benefits at the expense of various stakeholders. The size of the board affected the ability of the board to monitor and evaluate the management (Akhtaruddin et al., 2009, Zahra et al., 2000). The finance literature has generally found evidence consistent with the agency theory perspective that a smaller board is related to better firm performance for non-banking firms (Anderson and Reeb, 2004, Aebi et al., 2012). Boards of banking entities are quite different from boards of non-financial firms. In particular, boards in the banking sector tend to be bigger and more independent than those in the non-financial sector (Meyer et al., 2012).

In terms of board size, UT Bank consistently kept a smaller board of directors. Within the 9 years' period of consideration, UT Bank had average of 5 members in terms of board size with maximum of 7 members and minimum of 5 members on the board. Capital Bank also kept a smaller board size within its period of existence. That is, constant 5 members board. This act of the two banks keeping a smaller board size is in contradiction to the requirements of corporate governance practices for Banks and Financial Institutions in Ghana.

\subsection{Board Independence}

As part of corporate strategy, the board of directors played a fundamental role in determining the success of an organization. Adawi and Rwegasira (2011) affirmed that the board's effectiveness in performance must be determined by its independence because it is closely related to the strength of the board. In general, it is expected that independent directors display greater objectivity in their analysis of the management and behaviour of the company. Independent directors are more willing to undertake social commitments and to satisfy the interests of stakeholders (Ibrahim and Angelidis, 1995). In this respect, independent directors are seen as able to honour the obligations of the company. Higher proportion of independent directors improved the voluntary disclosure (Rouf and Abdur, 2011). Lim et al. (2007) suggested that independent directors provided more voluntary disclosures to reduce the information asymmetry between shareholders and managers. The presence of independent director reduces litigation risk and protects their reputation. It is also argued that efficiency goes concurrently with independence of board as evidenced by some authors in their studies (Haniffa and Hudaib, 2006). Previous studies by (Vafeas and Theodorou, 1998, Hermalin and Weisbach, 2001, Peng, 2004) argued that there is a positive relationship between independent directors and firm performance. Also (Fernandes, 2008) documented that firms with independent directors have less agency problems and have more alignment to shareholders.

As shown in table 1 unlike other financial institutions, the numbers of executive directors are more than the nonexecutive directors. Such structure impairs the independency of the board performance.

\subsection{Gender Diversity}

Gender diversity has become a topic of active policymaking in many countries, with some national governments establishing quotas for publicly traded and/or state-owned enterprises and others merely offering guidelines for diversity (Terjesen and Singh, 2008). Previous research suggests that most women directors are likely to possess staff/support managerial skills such as legal, human resources, communications, and public relations skills. 
Similarly, previous research brings up the idea of 'value in diversity', suggesting that female board members offer diverse viewpoints to the boardroom, help better represent all shareholders, and promote lively boardroom discussion (Letendre, 2004) and transparency (Upadhyay and Zeng, 2014). Given the 'glass ceiling' phenomenon, women also have to demonstrate additional competencies to reach directorship positions, which implies that women are quite likely to be highly proficient and diligent as directors (Eagly and Carli, 2003). Gender diversity in corporate boardrooms bring many benefits to the shareholder and work effectively to mitigate the possibility of expropriation. Fondas and Sassalos (2000) documented the presence of women on board increased the independence of the Board of Directors as well as provided distinctive quality of action from a different point of view in discussion in the boardroom by providing help and making a board interactive

Most studies suggest that gender diversity has a positive impact on firm performance. For example, (Brun et al., 2003) in the US, (Campbell and Mínguez-Vera, 2008) in Spain and (Gul et al., 2013) in Australia highlight this positive relationship between that women directors have a positive effect on financial performance. Recently, in microfinance institutions, the results note that more women are better able to lower operating costs (Chakrabarty and Bass, 2014) also found that women on board lower operation cost and improve financial performance in microfinance (Strøm et al., 2014). In addition, (Liu et al., 2014) study this issue for Chinese firms over the past decade and report that firm performance is positively related to gender diversity.

Women on Board has been a constant recommendation by the CG code for Ghana (Darko, 2016) but per findings from Table 1 and 2, both Capital Bank and UT bank did not pay heed to this recommendation. UT bank consistently had only one female or no female on the board while Capital Bank had no female on the board. Gender diversity as a good corporate governance principle was not a practiced by the two banks. They preferred to be male dominated or only males' board which is not a good practice.

\subsection{Expertise of Board}

According to (Ingley and Van Der Walt, 2005) "the concept of diversity relates to board composition and the varied combination of attributes, characteristics and expertise contributed by individual board members in relation to board process and decision making". In the UK, the Tyson Report 2003 has suggested that greater and diverse expertise among the board of directors will contribute towards enhanced organizational performance (Tyson 2003). Although diversity is often construed in terms of different professional affiliations, experience and expertise (Milliken and Martins, 1996), this emerging discourse is also related to changing socio-cultural attitudes towards age, ethnicity and biological gender. The importance of directors' backgrounds and characteristics beyond independence is increasingly being recognized (Hillman et al., 2000). According to (Ingley and Van Der Walt, 2005) "the concept of diversity relates to board composition and the varied combination of attributes, characteristics and expertise contributed by individual board members in relation to board process and decision making'".

Board of directors are expected to be from different professional background to enhance effective discussions in the boardroom. A critical look at the background of the board of directors for Capital Bank revealed that, the board chair is an educationist and entrepreneur. Two other board members are religious leaders. The other two board members were close friends who shared same vision with the board chair. It's clear that, the board composition was not a diverse board from different professions. Similar case was also seen with UT Bank. The board composition was friends of the co-founders of the bank. They had no previous knowledge in a profession that was related to the positions they occupied. Inadequate related professional experience of board members is likely to cause wrong decision and potential collapse

\subsection{CEO / Chairman Duality}

One of the important functions of the board of directors is to monitor the top management's actions, but a problem may arise when the Chief Executive Officer and chairperson positions are held by the same person. Unlike Agency Theory which shows that great conflicts may arise from the action of duality; Stewardship Theory supports the idea. Stewardship is one of the most important theories of Corporate Governance which states that managers don't work for their self-interest but they are working for the corporation favor, as they are steward for corporation assets. Managers are working for making high reputation for them and so benefit the corporation. Some examiners argued that the separation between Chief Executive Officer and the chairman is better for increasing the firm performance as mentioned by (Peel and O'Donnell, 1995, Coles et al., 2001). (Lu and Beamish, 2004)shows that there is a negative relationship between concentration leadership and firm performance. (Ujunwa, 2012) argued that role of duality may hinder the board to monitor management and therefore increase agency costs. (Kyereboah-Coleman, 2007) examined the relationship between CEO Duality and firm performance evidence experienced from Ghana. The study of Anthony relied on a secondary data from the financial statements of the 16 nonfinancial listed companies on Ghana stock market. Results of the study are consistent by other studies made by (Klapper and Love, 2002) which saw a negative relationship between leadership duality and firm's performance.

From Table 1 and Table 2, its clear that, in most instances, the position of CEO and board chairman was 
combined. This results in conflict of interest and can be a contributory factor to the collapse of the two banks. Per the CG principles for Financial Institutions in Ghana, CEO duality shouldn't be entertained so as to ensure effectiveness and disclosure of true performance of the bank.

\subsection{Committees of the board}

Board Committee members are appointed by the Board. Each Board Committee has its own terms of reference, duties and authorities as determined by the Board. Failure to have the appropriate committees with detailed responsibilities on the board could cause inefficiencies in the delivery of their duties. In the case of UT and Capital bank as can be seen from Table 3, they didn't have the appropriate committees and no detailed responsibilities were also available to the few committees that existed. Hence, the few committees acted base on their assumptions. Moreover, committees are expected to be chaired by non - executive directors. Again, in the case of UT and Capital Bank, they fell short to these corporate governance recommendations. Hence, inside directors were sometimes chairing committees of the board.

\section{Findings and Corporate Governance Lessons}

Table 1: Board Composition of UT Bank

\begin{tabular}{|c|c|c|c|c|c|c|}
\hline Year & Board Size & \multicolumn{2}{|c|}{ Board Independence } & \multicolumn{2}{c|}{ Gender Diversity } & CEO/Chairman Duality \\
\hline & & Inside Dir. & Outside Dir. & Male & Female & \\
\hline 2009 & 7 & 3 & 4 & 6 & 1 & Yes \\
\hline 2010 & 5 & 3 & 2 & 5 & 0 & Yes \\
\hline 2011 & 5 & 3 & 2 & 5 & 0 & Yes \\
\hline 2012 & 5 & 3 & 2 & 5 & 0 & Yes \\
\hline 2013 & 5 & 3 & 2 & 5 & 0 & Yes \\
\hline 2014 & 5 & 3 & 2 & 5 & 1 & No \\
\hline 2015 & 6 & 3 & 3 & 5 & 1 & No \\
\hline 2016 & 6 & 3 & 3 & 5 & 1 & \\
\hline
\end{tabular}

Table 2: Board Composition of Capital Bank

\begin{tabular}{|c|c|c|c|c|c|c|}
\hline Year & Board Size & \multicolumn{2}{|c|}{ Board Independence } & \multicolumn{2}{c|}{ Gender Diversity } & CEO/Chairman Duality \\
\hline & & Inside Dir. & Outside Dir. & Male & Female & \\
\hline 2013 & 5 & 1 & 4 & 5 & 0 & No \\
\hline 2014 & 5 & 1 & 4 & 5 & 0 & Yes \\
\hline 2015 & 5 & 1 & 4 & 5 & 0 & Yes \\
\hline 2016 & 5 & 1 & 4 & 5 & 0 & Yes \\
\hline
\end{tabular}

Table 3: Board Committees for UT and Capital Bank

\begin{tabular}{|c|c|c|c|c|c|c|c|c|c|c|c|c|}
\hline \multirow[t]{2}{*}{ Various Committees } & \multicolumn{8}{|c|}{ UT Bank } & \multicolumn{4}{|c|}{ Capital Bank } \\
\hline & 2009 & 2010 & 2011 & 2012 & 2013 & 2014 & 2015 & 2016 & 2013 & 2014 & 2015 & 2016 \\
\hline $\begin{array}{l}\text { Audit and Compliance } \\
\text { Committee }\end{array}$ & Yes & Yes & Yes & Yes & Yes & Yes & Yes & Yes & Yes & Yes & Yes & Yes \\
\hline $\begin{array}{l}\text { Large Credit Exposures/Non- } \\
\text { Executive Committee }\end{array}$ & & & & & & & & & & & & \\
\hline Nomination Committee & & & & & & & & & & & & \\
\hline Remuneration Committee & & & & Yes & & & & & & & & \\
\hline $\begin{array}{l}\text { Risk and Capital Management } \\
\text { Committee }\end{array}$ & & & & & & & & & & & Yes & Yes \\
\hline $\begin{array}{l}\text { Corporate Governance } \\
\text { Committee }\end{array}$ & Yes & Yes & Yes & Yes & Yes & Yes & Yes & Yes & Yes & Yes & Yes & Yes \\
\hline Others & & Yes & & & & & & & & & & \\
\hline
\end{tabular}


Table 4: Financial Institutions Standards of Board Composition

\begin{tabular}{|c|c|}
\hline Board Characteristic & Recommended Industry Standards \\
\hline Board Size & 15 \\
\hline Board Independence & $\begin{array}{l}\text { Independent Directors: } 12 \\
\text { Inside Directors: } 3\end{array}$ \\
\hline Gender Diversity & $\begin{array}{l}\text { Male: } 60 \% \\
\text { Females: } 40 \%\end{array}$ \\
\hline \multirow[t]{8}{*}{ Board Expertise } & Legal Professional \\
\hline & Former CEO with good reputation \\
\hline & Finance Professional \\
\hline & ICT Expert with top level management experience \\
\hline & Engineer with top level management experience \\
\hline & Chartered Accountant \\
\hline & Business Executive \\
\hline & Entrepreneur \\
\hline \multirow[t]{7}{*}{ Various Committees } & Audit and Compliance Committee \\
\hline & Large Credit Exposures/Non- Executive Committee \\
\hline & Nomination Committee \\
\hline & Remuneration Committee \\
\hline & Risk and Capital Management Committee \\
\hline & Corporate Governance Committee \\
\hline & Others \\
\hline
\end{tabular}

Source: Extracted from BOG website

\section{Conclusion}

Following the collapse of two commercial banks in Ghana, this study tries to investigate the cause of the collapse using common CG practices as stipulated for Financial Institutions in Ghana. The study examined the composition of board to see if the two banks followed the prescribed regulations.

Banks are to be committed to strong corporate governance practices that allocate rights and responsibilities among the Bank's shareholders, the Board and Executive Management to ensure efficient management of funds and continuity. Bank's corporate governance principles are contained in a number of corporate documents, including the Bank's Regulations, the Board of Directors Charter, Staff Service Rules and other policies issued from time to time.

The Board of Directors oversees the conduct of the Bank's business and is primarily responsible for providing effective governance over the Bank's key affairs, including the appointment of Executive Management, approval of business strategies, evaluation of performance and assessment of major risks facing the Bank. In discharging its obligations, the Board exercises judgment in the best interest of the Bank and relies on the Bank's Executive Management to implement approved business strategies, resolve day-to-day operational issues, keep the Board informed and maintain and promote high ethical standards. The Board delegates authority in management matters to the Bank's Executive Management subject to clear instructions in relation to such delegation of authority and the circumstances in which Executive Management shall be required to obtain Board approval prior to taking decisions on behalf of the Bank.

Our study reveals the weak compliance to common CG practices within the two banks. Specifically, the two banks had small board size as compared to the standard size of the banking industry. Also, the boards did not have enough committees to discharge its operation. The independence of the boards was also impaired as in most of the directors are executives. CEO duality resulted in conflict of interest and finally the non-executive directors have a close relationship with the promoters and executives.

\section{Recommendations}

The composition of the Board of Directors is a critical aspect to be taken into consideration because; their actions and inactions can cause some administrative lapses and eventually the collapse of the Bank. Boards of Banks are therefore expected to be a unitary Board which is made up of a majority of Non-Executive Directors.

In addition, Board should be made up of needed expects from different background to ensure diversity at boardroom discussions. Boards are also to put measures in place to have all recommended committees functioning 
effectively.

Lastly, Boards of Banks should be larger in size because Boards of banking entities are quite different from boards of non-financial firms. In particular, boards in the banking sector tend to be bigger and more independent than those in the non-financial sector

\section{References}

ADAMS, R. B. 2012. Governance and the financial crisis. International Review of Finance, 12, 7-38.

ADAWI, M. \& RWEGASIRA, K. 2011. Corporate boards and voluntary implementation of best disclosure practices in emerging markets: Evidence from the UAE listed companies in the Middle East. International Journal of Disclosure and Governance, 8, 272-293.

AEBI, V., SABATO, G. \& SCHMID, M. 2012. Risk management, corporate governance, and bank performance in the financial crisis. Journal of Banking \& Finance, 36, 3213-3226.

AHN, S., JIRAPORN, P. \& KIM, Y. S. 2010. Multiple directorships and acquirer returns. Journal of Banking \& Finance, 34, 2011-2026.

AKHTARUDDIN, M., HOSSAIN, M. A., HOSSAIN, M. \& YAO, L. 2009. Corporate governance and voluntary disclosure in corporate annual reports of Malaysian listed firms. Journal of Applied Management Accounting Research, 7, 1 .

ANDERSON, R. C. \& REEB, D. M. 2004. Board composition: Balancing family influence in S\&P 500 firms. Administrative science quarterly, 49, 209-237.

BEINER, S., DROBETZ, W., SCHMID, F. \& ZIMMERMANN, H. 2004. Is board size an independent corporate governance mechanism? Kyklos, 57, 327-356.

BHAGAT, S. \& BLACK, B. 2001. The non-correlation between board independence and long-term firm performance. J. CorP. l., 27, 231.

BODTKER, A. M. \& KATZ JAMESON, J. 2011. Emotion in conflict formation and its transformation: Application to organizational conflict management. International Journal of Conflict Management, 12, 259275.

BROWN, L. D. \& CAYLOR, M. L. 2004. Corporate governance and firm performance.

BRUN, T. A., CARTERET, H. A. \& AMBAINIS, A. 2003. Quantum to classical transition for random walks. Physical review letters, 91, 130602.

CAMPBELL, K. \& MÍNGUEZ-VERA, A. 2008. Gender diversity in the boardroom and firm financial performance. Journal of business ethics, 83, 435-451.

CHAKRABARTY, S. \& BASS, A. E. 2014. Corporate governance in microfinance institutions: board composition and the ability to face institutional voids. Corporate Governance: An International Review, 22, 367-386.

CLARKE, T. 2004. Cycles of Crisis and Regulation: the enduring agency and stewardship problems of corporate governance. Corporate Governance: An International Review, 12, 153-161.

CLARKE, T. 2007. International corporate governance: A comparative approach, Routledge.

COLES, J. W., MCWILLIAMS, V. B. \& SEN, N. 2001. An examination of the relationship of governance mechanisms to performance. Journal of management, 27, 23-50.

COMMISSION, H. R. 2003. Report of the HIH Royal Commission. Volume I: The Failure of HIH: A Corporate Collapse and Its Lessons, 2.

DONNELLY, R. \& MULCAHY, M. 2008. Board structure, ownership, and voluntary disclosure in Ireland. Corporate Governance: An International Review, 16, 416-429.

EAGLY, A. H. \& CARLI, L. L. 2003. The female leadership advantage: An evaluation of the evidence. The leadership quarterly, 14, 807-834.

FERNANDES, N. 2008. EC: Board compensation and firm performance: The role of "independent" board members. Journal of multinational financial management, 18, 30-44.

FONDAS, N. \& SASSALOS, S. 2000. A different voice in the boardroom: How the presence of women directors affects board influence over management. Global focus, 12, 13-22.

GATSI, J. G. \& AKOTO, R. K. 2010. Capital structure and profitability in Ghanaian banks.

GERXHANI, K. 2004. The informal sector in developed and less developed countries: a literature survey. Public choice, 120, 267-300.

GOMPERS, P., ISHII, J. \& METRICK, A. 2003. Corporate governance and equity prices. The quarterly journal of economics, 118, 107-156.

GRAIS, W. \& PELLEGRINI, M. 2006. Corporate governance in institutions offering Islamic financial services: issues and options, World Bank Publications.

GUL, F. A., HUTCHINSON, M. \& LAI, K. M. 2013. Gender-diverse boards and properties of analyst earnings forecasts. Accounting Horizons, 27, 511-538.

HANIFFA, R. \& HUDAIB, M. 2006. Corporate governance structure and performance of Malaysian listed companies. Journal of Business Finance \& Accounting, 33, 1034-1062. 
HERMALIN, B. E. \& WEISBACH, M. S. 2001. Boards of directors as an endogenously determined institution: A survey of the economic literature. National Bureau of Economic Research.

HILlMAN, A. J., CANNELlA, A. A. \& PAETZOLD, R. L. 2000. The resource dependence role of corporate directors: Strategic adaptation of board composition in response to environmental change. Journal of Management studies, 37, 235-256.

IBRAHIM, N. A. \& ANGELIDIS, J. P. 1995. The corporate social responsiveness orientation of board members: Are there differences between inside and outside directors? Journal of business Ethics, 14, 405-410.

IJIMDIYA, L. S. 2016. THE LEGAL AND INSTITUTIONAL FRAMEWORK FOR THE OPERATION OF DEPOSIT INSURANCE SCHEME IN NIGERIA.

INGLEY, C. \& VAN DER WALT, N. 2005. Do board processes influence director and board performance? Statutory and performance implications. Corporate Governance: An International Review, 13, 632-653.

KLAPPER, L. F. \& LOVE, I. 2002. Corporate governance, investor protection and performance in emerging markets.

KLAPPER, L. F. \& LOVE, I. 2004. Corporate governance, investor protection, and performance in emerging markets. Journal of corporate Finance, 10, 703-728.

KYEREBOAH-COLEMAN, A. 2007. Relationship between corporate governance and firm performance: An African perspective.

LETENDRE, L. 2004. The dynamics of the boardroom. The Academy of Management Executive, 18, 101-104.

LIM, S., MATOLCSY, Z. \& CHOW, D. 2007. The association between board composition and different types of voluntary disclosure. European Accounting Review, 16, 555-583.

LIU, Y., WEI, Z. \& XIE, F. 2014. Do women directors improve firm performance in China? Journal of Corporate Finance, 28, 169-184.

LU, J. W. \& BEAMISH, P. W. 2004. International diversification and firm performance: The S-curve hypothesis. Academy of management journal, 47, 598-609.

MACCARTHY, J. \& DERY, L. 2016. Banking Regulatory and Market Framework in Ghana: Strength, Weaknesses, Opportunities and Threats.

MACDONALD, G. 1998. The Gold Coast Past and Present: A Short Description of the Country and its People, Longmans, Green.

MEYER, M., KIRCHER, M., GANSAUGE, M.-T., LI, H., RACIMO, F., MALLICK, S., SCHRAIBER, J. G., JAY, F., PRÜFER, K. \& DE FILIPPO, C. 2012. A high-coverage genome sequence from an archaic Denisovan individual. Science, 338, 222-226.

MILLIKEN, F. J. \& MARTINS, L. L. 1996. Searching for common threads: Understanding the multiple effects of diversity in organizational groups. Academy of management review, 21, 402-433.

NERANTZIDIS, M., FILOS, J. \& LAZARIDES, T. G. 2012. The puzzle of corporate governance definition (s): A content analysis.

NICHOLSON, G. J. \& KIEL, G. C. 2004. Breakthrough board performance: how to harness your board's intellectual capital [1]. Corporate Governance: The international journal of business in society, 4, 5-23.

OWUSU, G., OWUSU, A. Y., OTENG-ABABIO, M., WRIGLEY-ASANTE, C. \& AGYAPONG, I. 2016. An assessment of households' perceptions of private security companies and crime in urban Ghana. Crime Science, 5,5 .

PEEL, M. J. \& O'DONNELL, E. 1995. Board structure, corporate performance and auditor independence. Corporate governance: An international review, 3, 207-217.

PENG, M. W. 2004. Outside directors and firm performance during institutional transitions. Strategic management journal, 25, 453-471.

ROBERTS, J., MCNULTY, T. \& STILES, P. 2005. Beyond agency conceptions of the work of the non-executive director: Creating accountability in the boardroom. British journal of management, 16.

ROUF, D. \& ABDUR, M. 2011. The corporate social responsibility disclosure: a study of listed companies in Bangladesh.

SELVAGGI, M. \& UPTON, J. 2008. Governance and performance in corporate Britain. ABI research paper, 7.

STIGLITZ, J. E. \& UY, M. 1996. Financial markets, public policy, and the East Asian miracle. The World Bank Research Observer, 11, 249-276.

STRØM, R. Ø., D’ESPALLIER, B. \& MERSLAND, R. 2014. Female leadership, performance, and governance in microfinance institutions. Journal of Banking \& Finance, 42, 60-75.

TERJESEN, S. \& SINGH, V. 2008. Female presence on corporate boards: A multi-country study of environmental context. Journal of business ethics, 83, 55-63.

UJUNWA, A. 2012. Board characteristics and the financial performance of Nigerian quoted firms. Corporate Governance: The international journal of business in society, 12, 656-674.

UPADHYAY, A. \& ZENG, H. 2014. Gender and ethnic diversity on boards and corporate information environment. Journal of Business Research, 67, 2456-2463. 
VAFEAS, N. \& THEODOROU, E. 1998. The relationship between board structure and firm performance in the UK. The British Accounting Review, 30, 383-407.

WOLDIE, A., HINSON, R., IDDRISU, H. \& BOATENG, R. 2008. Internet banking: an initial look at Ghanaian bank consumer perceptions. Banks and Bank Systems, 3, 35-46.

ZAHRA, S. A., NEUBAUM, D. O. \& HUSE, M. 2000. Entrepreneurship in medium-size companies: Exploring the effects of ownership and governance systems. Journal of management, 26, 947-976. 